\title{
What is Islamic Medicine? How Does It Relate to Contemporary Medicine?
}

$\mathrm{M}$ T. Rehman et al described different concepts of disease and different therapeutic models in different traditions and philosophies in their article "Therapeutic Interventions: An Islamic Perspective."1 They compared and contrasted these with the Islamic medical tradition. The main features of the latter as described by these authors are belief that there is a cure for each disease (except senility), that the disease is a test from Allah alle, and that Allah dite ultimately causes cure. The authors further state that Islam stresses the spiritual role in healing, i.e. true belief in God $d \vec{l}$, ritual prayer, supplication, and reading the Qur'an. The authors state the fact that the Islamically prescribed lifestyle leads to health, protects from disease, and plays a role in achieving cure of disease. The authors maintain that Muslims are not prohibited from accepting and utilizing other therapeutic strategies, including alternative medicine and "Western" medicine as long as one does not use any prohibited item or technology and as long as the Muslim patient still firmly believes that the ultimate cure is from Allah dist. They advocate that Muslim scientists design strategies to evaluate empirical evidence for the analysis of guidelines describing healthrelated issues from the Qur'an and Sunnah.

The authors used the term "Islamic medical tradition" to describe what many have referred to as Islamic medicine This article is apt to cause discussion about the definition of Islamic medicine and the relationship between Islam and contemporary science in general and medical sciences in particular. The term Islamic medicine has been used for several decades, and still no consensus has arisen on its definition. I tried to briefly make distinctions between altibb al-nabawi (Prophetic medicine), Unani medicine, and Islamic medicine in an editorial note to the article, 1 but a more detailed discussion of the definition of Islamic medicine is warranted.

The concept of Islamic medicine has been advanced by other senior members of the Islamic Medical Association of North America (IMANA), particularly by Drs. Ahmad Elkadi and Husain Nagamia.
Dr. Elkadi presented this concept in an IMANA meeting in 1983. He defined Islamic medicine as "The most up-to-date medical science and technology combined and conforming with the Divine teachings of Islam." 2 Dr. Nagamia, the chair of the International Institute of Islamic Medicine (IIIM), defined Islamic medicine as "modern medicine with an Islamic perspective." However, he stresses the definition of Islamic medicine as medicine practiced by the eminent Muslim physicians during the heyday of Islamic civilization. He also listed other definitions to include al-tibb alnabawi, the Unani medicine primarily practiced today in the Indian subcontinent by hakims or the medical tradition that utilizes herbs, seeds and honey for treatment. ${ }^{3}$ Dr. Nagamia later added to the definition "medicine that is practiced within the confines and laws established by the shariah." ${ }^{4}$ Dr. Shahid Athar ${ }^{5}$ and Dr. Abdul Rahman al-Awadi ${ }^{6}$ also have contributed to this discussion.

I wanted to hear from new members of IMANA about their concept of Islamic medicine. I invited Dr. Jalees Rehman to comment on the article by M.T. Rehman et al. In his guest editorial, he stressed the complexity of the relationship between religion and biomedical sciences.7 He states that "the concept of Islamic medicine is very problematic." He then used some possible definitions but did not indicate which one he believes, if any. While I believe that all of us agree that we should not use prohibited items or technology for therapy, I know of nobody who has advocated that Muslims should only use therapeutic approaches directly based on the texts of Qur'an and Sunnah, and IMANA does not advocate that strict definition of Islamic medicine.

Dr. Jalees Rehman questions whether, in the context of Islamic medicine, Muslims can be treated by non-Muslims. The fact that Muslims believe that cure is caused by Allah alle does not mean that Muslims should not accept treatment by non-Muslims (a surgeon as an example given by Dr. Jalees Rehman). Allah de created the nonbelieving surgeon and gave him the knowledge and the competence to treat the 
patient. If He wills, Allah alitwill heal the patient through this surgeon. A Muslim submitting to surgery by a nonbeliever is not denying the supremacy of Allah ing from early Islam. ${ }^{8}$ Historically, it is documented that rulers had non-Muslim physicians in their courts. ${ }^{9}$ A particularly outstanding example is Mūsā ibn Maymūn's employment in the court of the Sultān Șalāḥ al-Dīn al-Ayyūbī.10

Dr. Jalees Rehman cautions that continued advocacy of Islamic medicine may lead to conflicts when therapies based on the Qur'an and Sunnah may not be supported by current medical knowledge. He cites the example of the use of honey in diabetics. First, one cannot take a general reference in the Qur'an to mean a specific treatment modality. For example, the Qur'an states:

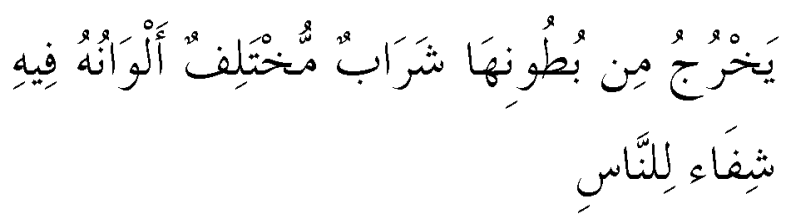

... there issues from within the [bees'] bodies a drink of varying colors, wherein is healing for men. ${ }^{11}$

This verse does not necessarily mean that it is a cure for all kinds of ailments, and definitely it does not mean that one is prohibited from seeking other treatments for different ailments. Second, Muslims should not doubt the truth of God's words ali. If we do not know the meaning embedded in this passage, maybe in the future new information will give us more insight on the curative effects of honey. So we should investigate the potential benefits of honey and other foods mentioned in the Qur'an or hadiths of the Prophet Muhammad aلd allate. As a matter of fact, there are some studies that show that honey and black seed enhance the immune function and thus may be useful in the treatment of a broad variety of conditions in which compromised immunity plays a role. ${ }^{2}$ These studies need to be corroborated. Also needed are studies of the use honey, specifically in diabetics.

Further, research should be directed towards the study of stress-reducing effects of the Qur'an. Such studies have been performed, and they have documented such effects. ${ }^{2}$ However, other studies need to be performed to support these findings. In conducting such studies, one has to use valid scientific methods. Dr. Jalees Rehman is correct in cautioning Muslim scholars to avoid selectively choosing empirical results that support scripture when trying to prove the empirical validity of the scripture.

Dr. Jalees Rehman is also correct in stating that one does not need to look at Islamic medicine broadly defined ${ }^{2-4}$ and the biomedical disease models as distinct opposing models. They interact.

As Muslims we need to advance the biomedical disease model but without compromising our core Islamic belief/value system. Allah wal knows best.

I invite readers to respond to the intriguing opinions expressed in Dr. M.T. Rehman et al's article, Dr. Jalees Rehman's guest editorial, and this editorial.

\section{Wassalaam,}

\section{Hossam E. Fadel, MD, PhD, FACOG \\ Editor-in-Chief, JIMA \\ Maternal Fetal Medicine \\ University Hospital \\ Clinical Professor, Medical College of Georgia \\ Augusta, Georgia}

\section{References}

1. Rehman MT, Nazer R, Brown, L et al. Therapeutic interventions: an Islamic perspective. J Islam Med Assn. 2008;40:60-8.

2. Elkadi A. Islamic medicine in North America. J Islam Med Assn. 1984;16:8-10.

3. Nagamia HF. International Institute of Islamic Medicine. J Islam Med Assn. 1993;25:4-6.

4. Nagamia HF. New definition of Islamic medicine: 'Neo-Islamic Medicine.' J Islam Med Assn. 1996;28:100-1.

5. Athar S. Contemporary issues in the practice of Islamic medicine. J Islam Med Assn. 1996;28:195-7.

6. al-Awadi AR. The role of the Islamic organization for medical sciences in reviving Islamic medicine. J Islam Med Assn. 2000;32:68-72.

7. Rehman J. Oversimplifying the complex relationship between religion and biomedical science: does it serve either? J Islam Med Assn. 2008:40:54-5.

8. Ahmad ibn Naqib al-Misri. The reliance of the traveller. Nuh Ha Mim Keller (editor and translator). Modern Printing Press: Dubai; 1991. 
9. Nagamia HF, Puyan N. Abū Zayd Hunayn ibn Ishāq al-'Ibādī: a physician translator par excellence. J Islam Med Assn. 2008;40;9-14.

10. Raddawi HM. Moses Maimonides (Mūsā ibn
Maymūn), a Jewish philosopher, theogian and physician: his life and works, an Islamic perspective. J Islam Med Assn. 2006:38:27-33.

11. Glorious Qur'an, Chapter 16, Verse 69. 